\title{
Sternal Chondromyxoid Fibroma
}

National Cancer Institute

\section{Source}

National Cancer Institute. Sternal Chondromyxoid Fibroma. NCI Thesaurus. Code C6714.

An uncommon benign cartilag inous neoplasm arising from the sternum. It is

characterized by the presence of spindle-shaped or stellate chondrocytes, a lobulated growth pattern, myxoid stroma formation, and sometimes multinucleated giant cells. 